\title{
The Effectiveness of Facebook Groups for e-Learning
}

\author{
Chen-Huei Chou and Shih-Ming Pi
}

\begin{abstract}
E-learning is a new approach for teaching and learning using telecommunication technology such as the Internet. Learners can receive knowledge anytime, anywhere. In order to understand the factors influencing learners' intention to use e-learning systems and the effectiveness using the systems, recent studies designed different learning methods over various learning systems. However, most of the studies focused on the one-way e-learning systems. In such systems, the communications are mainly between learners and instructors. We argued that peer interactions play an important role on e-learning. Using Facebook Groups for School as the e-learning platform, we empirically tested the proposed model. We found that technology quality and interaction with instructor would affect learners' perceived satisfaction. The interaction with peers and learners' satisfaction would influence the intention of continuous use of the course Facebook Groups as a learning support.
\end{abstract}

Index Terms-E-learning, facebook groups for schools, interaction with peers, interaction with instructor.

\section{INTRODUCTION}

Information systems are commonly used in modern organizations to improve efficiency, reduce costs, automation, etc. However, ineffective interaction between users and the system is one of the major issues for the failure of the adoption of a new system. End-user training is one of the key methods for the remedy.

When adopting a new system, enterprise resource planning for example, enterprises arranged $10 \%$ to $20 \%$ of the cost on average on end-user training [1]. The training includes the use of computers and information systems. Bostrom, Olfman, and Sein [2] proposed a framework for end-user computing which incorporated the theories in cognitive psychology, educational psychology, information science, computer science, and other fields. They found that when trainees learned a target system, individual differences, the target system, along with training method would influence trainees' mental model and thus affect their learning performance. In addition, different users (e.g. middle level management, entry level management) required different knowledge of system operations. Therefore, the end-user training needed to provide different level of knowledge according to users' needs [3]. Moreover, early organizations focused on end-user training in a structured environment such as a classroom and sought for an advanced training method called "demand pull". Due to the advance of technology and ubiquitous

Manuscript received April 4, 2014; revised June 13, 2014.

Chen-Huei Chou is with School of Business, College of Charleston, Charleston SC 29464 USA (e-mail: chouc@cofc.edu).

Shih-Ming Pi is with the Department of Information Management, School of Business, Chung Yuan Christian University, Chung Li, Taiwan 32023 ROC (e-mail: smpi@im.cycu.edu.tw). telecommunication development, more and more organizations have started to adopt technologies for training [4].

E-learning systems deliver training materials synchronous or asynchronous to multiple distant locations. They may be capable of distributing training over the LAN, WAN, or Internet [5]. Such systems provide a new learning method for learners to study at anytime, anywhere based on their own pace. Due to the popularity of e-learning systems, recent studies investigated factors influencing learners' willingness to use the system and their learning performance, controlled by different types of media and learning methods. For example, Choi et al. [5] used flow theory and theory of reasoned action to examine the factors influencing learning performance over a web-based electronic learning system on ERP training. However, most of the past studies relied on one-way e-learning systems. These systems mimicked the traditional setting linking one instructor to multiple learners. Learners' interaction was neglected.

Facebook is one of the mainstream social networking sites. It offers its users to share, post, chat, create events, run applications, and interact with others online. Users can also establish their own Groups and Pages. Facebook has offered Groups for Schools since 2012. Students and faculty can join groups and create their own groups using qualified e-mail addresses associated with educational institutions. The Groups for Schools can be used for a class or a club. Interactivity is one of the major benefits provided by social networking sites like Facebook.

In this study, we plan to fill the gap by investigating the factors of learner's satisfaction and their willingness of continuous use of an e-learning system with interactivity. Specifically, we utilized Facebook Groups for Schools to create an interactive learning environment.

The rest of the paper is organized as follows. We first review the literature. Next, we discuss our research model and data collection. In the Section IV, we provide the results of the study. Finally, the conclusion and discussions are presented.

\section{BACKGROUND}

\section{A. End-User Training}

Incorporating with the theories in cognitive psychology, educational psychology, information systems, and computer science, Bostrom et al. [2] proposed an end-user training research framework which consists of five variables - target system, training methods, individual differences, mental model, and training outcomes. Their findings suggested that different training methods should be used for different learners. Due to learners' different needs, it was recommended to provide application-based training to 
concrete learners, while construct-based training was suggested to be given to abstract learners.

In addition, Compeau, Olfman, Sein, and Webster [6] proposed a framework for the training and learning process which consists of initiation phase, formal training and learning phase, and post-training phase. The training design, delivery, and effectiveness would be affected by trainee, software, task/job and organizational characteristics. During the initiation phase, it was suggested to 1) determine training needs, 2) develop training materials and methods, 3) design the training environment, 4) select trainees, 5) compose training groups based on trainees' needs, and 6) train trainers. The training is conducted during the training and learning phase. Right after training, it was recommended to evaluate the training and learning immediately during the post-training phase. Management may examine whether the training has been transferred to the workplace while trainees are supported.

Moreover, Sein et al. [3] proposed a training strategy framework. Based on learners' types (e.g. upper level management, middle level management, entry level workers, etc.) and their different knowledge levels, different information technology (IT) tools and different training methods were suggested. Since different users may require different level of knowledge for using a particular IT tool, different ways to deliver knowledge should be used.

\section{B. E-Learning Systems}

E-learning is a method of training and education using telecommunication technology to delivery knowledge. Unlike traditional face-to-face learning methods, it is not limited to time and location. E-learning systems provide a virtual learning environment for learners and instructors to participate. The virtual learning environments were defined as "computer-based environments that are relatively open systems, allowing interactions and encounters with other participants" [7]. Piccoli et al. [8] proposed a framework to examine the effectiveness of virtual learning environment. This framework consists of factors in human dimension and design dimension. Students and instructors are two major players in human dimension. Design dimension includes learning model such as objectivist, constructivist, technology, learner control, content, and interaction. It was suggested that enhanced technology comfort and reduced computer anxiety would achieve better learning performance. Also, learners' performance would be affected by instructors' interaction style (e.g. timing, frequency, quantity) and technology control.

User satisfaction is one of the important factors influencing the success of an information system [9]. Inspired by Piccoli et al. [8] framework, other studies investigated the factors of user satisfaction from six dimensions which include student, teacher, technology, system design, course, and environmental dimension [10]-[12].

\section{RESEARCH DESIGN}

\section{A. Research Model}

Inspired by prior important e-learning studies such as Sein el al. [2], Piccoli et al. [8], and Sun et al. [13], we developed a research model (Fig. 1) in order to examine the factors influencing the success of the use of Facebook Groups as an e-learning environment to support a face-to-face course.

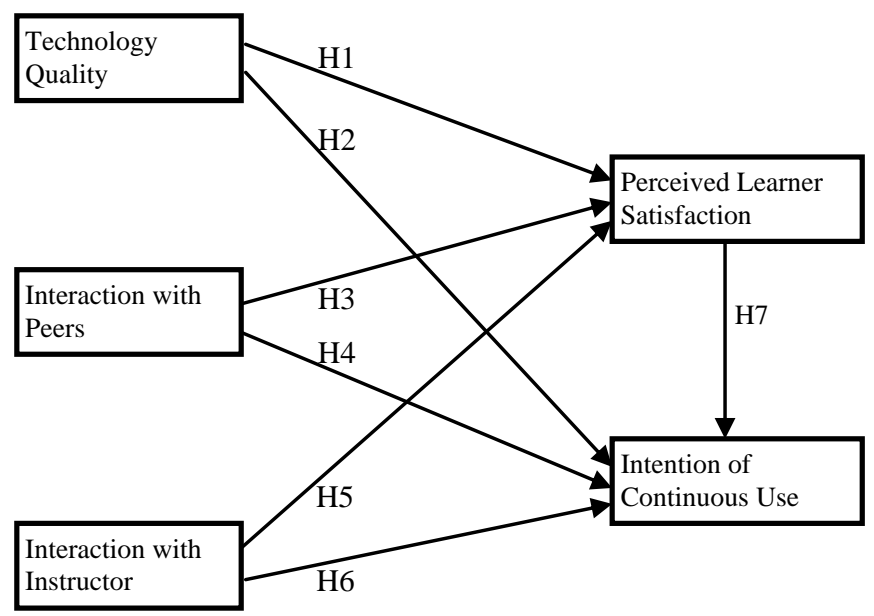

Fig. 1. Research model.

Since Facebook Groups is a relatively new platform for e-learning, we mainly focus on the factors in technology and interaction dimensions. Here is a list of hypotheses we plan to test:

H1: Technology quality will influence perceived learner satisfaction with the course Facebook Groups.

$H 2$ : Technology quality will influence learner's intention to continuously use the course Facebook Groups.

H3: Learner's interaction with peers online will influence perceived learner satisfaction with the course Facebook Groups.

H4: Learner's interaction with peers online will influence learner's intention to continuously use the course Facebook Groups.

H5: Learner's interaction with instructor online will influence perceived learner satisfaction with the course Facebook Groups.

H6: Learner's interaction with instructor online will influence the learner's intention to continuously use the course Facebook Groups.

H7: The perceived learner satisfaction with the course Facebook Groups will influence the learner's intention to continuously use the Groups.

\section{B. Measurement Development}

We conducted interviews with experienced e-learners and Facebook users to identify the scope of measurements. Table I summaries the operational definitions of the constructs in the research model.

Questionnaire items were developed based on the literature of e-learning and then pilot tested by two experts of e-learning. 7-point Likert scale was used for the items related to the research model. Other user profile items such as the average amount of time spent, the number of posts, the number of "Like" clicks, and the number of messages left in the Groups were included in the questionnaire.

\section{Data Collection}

We used the students who took an elective software project management course. During the course period, they 
were asked to participate in the course Facebook Groups. Based on different subjects in the course, they may ask questions, share information, discuss, agree on others' post through a click of "Like", and receive feedback from instructor. Questionnaire was distributed at the end of semester.

TABLE I: DEFINITION OF CONSTRUCTS IN RESEARCH MODEL

\begin{tabular}{ll}
\hline \hline Construct & Operational Definition \\
\hline Technology Quality & $\begin{array}{l}\text { Functionality and ease of use of a system } \\
\text { which includes user friendly interface } \\
\text { and intuitive user interface. }\end{array}$ \\
Interaction with Peers & $\begin{array}{l}\text { Learners' interactions with others over } \\
\text { the course Facebook Groups. The } \\
\text { interaction includes discussions, sharing, } \\
\text { comments, etc. }\end{array}$ \\
Interaction with Instructor & $\begin{array}{l}\text { Learners' interactions with the instructor. } \\
\text { The interaction includes discussions, } \\
\text { communications, and instructor's } \\
\text { feedback. } \\
\text { Learners' intention to continue using } \\
\text { Perceived Learner }\end{array}$ \\
Satisfaction & $\begin{array}{l}\text { course Facebook Groups. } \\
\text { using the course Facebook Groups. }\end{array}$ \\
\hline \hline
\end{tabular}

\section{DATA ANALYSIS}

\section{A. Summary of Descriptive Statistics}

At the end of the software project management course, we distributed the questionnaire to 107 students. We collected 96 useable complete responses, with the response rate close to $90 \% .49$ were male $(51 \%)$ and 47 were female (49\%). The descriptive statistics about their participation of the course Facebook Groups are summarized in Table II. Most of the participants $(68.8 \%)$ spent 2-6 hours per week on the course Facebook Groups. A large group $(62.5 \%)$ of them had less than 2 posts. $58.3 \%$ of the participants clicked the "Like" button on more than 10 posts. The number of messages left was similar in different categories.

TABLE II: SUMMARY OF PARTICIPATION IN COURSE FACEBOOK GROUP

\begin{tabular}{lccc}
\hline \hline Activity & & Frequency & Percentage \\
\hline Time spent every week & $<2$ hours & 14 & 14.6 \\
& $2-6$ hours & 66 & 68.8 \\
& $>6$ hours & 16 & 16.7 \\
The number of posts & $<2$ times & 60 & 62.5 \\
& $2-4$ times & 17 & 17.7 \\
& $4-6$ times & 10 & 10.4 \\
Number of clicks on & $>6$ times & 9 & 9.4 \\
"Like" & $<5$ times & 9 & 9.4 \\
& $5-10$ times & 31 & 32.3 \\
Number of messages left & $>10$ times & 56 & 58.3 \\
& $<2$ times & 29 & 30.2 \\
& $2-5$ times & 30 & 31.3 \\
& $5-10$ times & 24 & 25.0 \\
& $>10$ times & 13 & 13.5 \\
\hline \hline
\end{tabular}

\section{B. Measurement Model Analysis}

The research model shown in Fig. 1 was analyzed using partial least squares (PLS) method. PLS is a technique to examine and construct a structural model for analyzing relationship between latent variables. The benefits using PLS include 1) it takes multiple independent and dependent variables. 2) it overcomes multicolinearity. 3) it can deal with reflective and formative indicators in one model. 4) it takes small samples. 5) it does not require multivariate normal because of fixed point estimation.

SmartPLS software (http://www.smartpls.de/) was used for PLS analysis. First, reliability and validity were accessed. Second, the predictive power was evaluated based on the significance of path coefficients. Because of relatively small sample size used in this study, a bootstrapping resampling method was used to obtain 500 observations.

\section{Reliability and Validity}

We applied commonly acceptable thresholds for evaluating our research model. Convergent validity can be ensured when all factors' own loadings are greater than cross-loadings. It was suggested that all factor loadings should exceed 0.5 [14]. Composite reliability (CR) should be greater than 0.7 [15]. The Cronbach's $\alpha$ was suggested to exceed 0.7 [16]. The average variance extracted (AVE) was recommended to exceed 0.5 [17]. Discriminant validity was made when the square root of the AVE for each construct exceeds other correlation coefficient of the construct [18].

We summarized the measurement analysis in Table III. The results exceeded all the suggested thresholds in the literature. The factor loadings were all above 0.8 , greater than the suggested 0.5 . The composite reliability of the constructs was $0.955,0.918,0.894,0.980$, and 0.972 , respectively. All values were far above the suggested 0.7. The Cronbach's $\alpha$ of each construct was also greater than the suggested 0.7, demonstrating the reliability and validity of constructs. Also, all AVEs were above the suggested 0.5. Discriminant validity was made because the square root of the AVE for each construct exceeded other correlation coefficient of the construct (see the correlation coefficient matrix in Table IV).

TABLE III: RESULTS OF VALIDITY AND RELIABILITY ANALYSIS

\begin{tabular}{|c|c|c|c|c|c|c|c|c|}
\hline Construct & Item & Mean & S.D. & F.L. & $t$ Value & AVE & $\mathrm{CR}$ & $\alpha$ \\
\hline \multirow{3}{*}{$\begin{array}{c}\text { Technology } \\
\text { Quality }\end{array}$} & IT_1 & 5.73 & 0.93 & 0.850 & 90.39 & \multirow{3}{*}{0.875} & \multirow{3}{*}{0.955} & \multirow{3}{*}{0.929} \\
\hline & IT_2 & 5.71 & 0.96 & 0.910 & 45.87 & & & \\
\hline & IT_3 & 5.90 & 0.88 & 0.866 & 46.61 & & & \\
\hline \multirow{2}{*}{$\begin{array}{l}\text { Interaction } \\
\text { with Peers }\end{array}$} & STU_1 & 5.96 & 0.87 & 0.849 & 66.10 & \multirow{2}{*}{0.849} & \multirow{2}{*}{0.918} & \multirow{2}{*}{0.823} \\
\hline & STU_2 & 5.69 & 0.96 & 0.849 & 35.12 & & & \\
\hline \multirow{2}{*}{$\begin{array}{c}\text { Interaction } \\
\text { with } \\
\text { Instructor }\end{array}$} & TEA_1 & 5.69 & 0.96 & 0.809 & 48.89 & \multirow[b]{2}{*}{0.809} & \multirow{2}{*}{0.894} & \multirow{2}{*}{0.765} \\
\hline & TEA_2 & 5.73 & 1.03 & 0.809 & 26.74 & & & \\
\hline \multirow{2}{*}{$\begin{array}{l}\text { Intention of } \\
\text { Continuous } \\
\text { Use }\end{array}$} & INT_1 & 5.42 & 1.05 & 0.960 & 110.57 & \multirow[b]{2}{*}{0.960} & \multirow[b]{2}{*}{0.980} & \multirow[b]{2}{*}{0.958} \\
\hline & INT_2 & 5.39 & 1.05 & 0.960 & 114.36 & & & \\
\hline \multirow{4}{*}{$\begin{array}{c}\text { Perceived } \\
\text { User } \\
\text { Satisfaction }\end{array}$} & SAT_1 & 5.05 & 1.06 & 0.864 & 43.25 & \multirow{4}{*}{0.898} & \multirow{4}{*}{0.972} & \multirow{4}{*}{0.962} \\
\hline & SAT_2 & 5.10 & 1.10 & 0.916 & 69.23 & & & \\
\hline & SAT_3 & 5.06 & 1.10 & 0.915 & 79.36 & & & \\
\hline & SAT_4 & 5.18 & 0.98 & 0.897 & 62.08 & & & \\
\hline $\begin{array}{l}\text { S.D.: } \\
\text { F.L.: } \\
\text { AVE } \\
\text { CR: } \\
\alpha: C r\end{array}$ & $\begin{array}{l}\text { andarc } \\
\text { ctor L } \\
\text { verag } \\
\text { nposit }\end{array}$ & $\begin{array}{l}\text { ling; } \\
\text { ariai } \\
\text { lelia }\end{array}$ & $\begin{array}{l}E x \\
y ;\end{array}$ & cted; & & & & \\
\hline
\end{tabular}

Table $\mathrm{V}$ shows the factor loading of each item in the questionnaire. The own-loadings were all greater than the cross-loadings. All items in a construct were well loaded to the construct, but not others. 
TABLE IV: CORRELATION COEFFICIENT MATRIX

\begin{tabular}{l|c|c|c|c|c}
\hline \hline & $\begin{array}{c}\text { Technology } \\
\text { Quality }\end{array}$ & $\begin{array}{l}\text { Interaction } \\
\text { with Peers }\end{array}$ & $\begin{array}{c}\text { Interaction } \\
\text { with } \\
\text { Instructor }\end{array}$ & $\begin{array}{c}\text { Intention of } \\
\text { Continuous } \\
\text { Use }\end{array}$ & $\begin{array}{c}\text { Perceived } \\
\text { User } \\
\text { Satisfaction }\end{array}$ \\
\hline $\begin{array}{l}\text { Technology } \\
\text { Quality }\end{array}$ & $\mathbf{0 . 9 3 5 5}$ & & & & \\
\hline $\begin{array}{l}\text { Interaction } \\
\text { with Peers }\end{array}$ & 0.6708 & $\mathbf{0 . 9 2 1 2}$ & & & \\
\hline $\begin{array}{l}\text { Interaction } \\
\text { with } \\
\text { Instructor }\end{array}$ & 0.5835 & 0.8222 & $\mathbf{0 . 8 9 9 5}$ & & \\
\hline $\begin{array}{l}\text { Intention of } \\
\text { Continuous } \\
\text { Use }\end{array}$ & 0.6274 & 0.6753 & 0.6445 & $\mathbf{0 . 9 7 9 7}$ & \\
\hline $\begin{array}{l}\text { Perceived } \\
\text { User } \\
\text { Satisfaction }\end{array}$ & 0.5654 & 0.5366 & 0.5487 & 0.7750 & $\mathbf{0 . 9 4 7 5}$ \\
\hline \hline
\end{tabular}

Note: The values in diagonal are the square root of AVEs

TABLE V: CROSS-LOADING VALIDATION

\begin{tabular}{cccccc}
\hline \hline Item & IT & STU & TEA & INT & SAT \\
\hline IT_1 & $\mathbf{0 . 9 5 3 8}$ & 0.6059 & 0.5118 & 0.5897 & 0.5484 \\
IT_2 & $\mathbf{0 . 9 2 6 2}$ & 0.5942 & 0.5281 & 0.5497 & 0.500 \\
IT_3 & $\mathbf{0 . 9 2 6 2}$ & 0.6794 & 0.5956 & 0.6181 & 0.5362 \\
STU_1 & 0.5542 & $\mathbf{0 . 9 1 0 2}$ & 0.7698 & 0.5942 & 0.5339 \\
STU_2 & 0.4928 & $\mathbf{0 . 8 8 8 6}$ & 0.7445 & 0.5642 & 0.4494 \\
TEA_1 & 0.6341 & 0.7739 & $\mathbf{0 . 9 3 3 4}$ & 0.6475 & 0.5515 \\
TEA_2 & 0.6005 & 0.7023 & $\mathbf{0 . 9 0 8 9}$ & 0.5939 & 0.429 \\
INT_1 & 0.6220 & 0.6735 & 0.6401 & $\mathbf{0 . 9 7 9 6}$ & 0.7491 \\
INT_2 & 0.6073 & 0.6497 & 0.6227 & $\mathbf{0 . 9 7 9 7}$ & 0.7693 \\
SAT_1 & 0.5884 & 0.4733 & 0.4969 & 0.7326 & $\mathbf{0 . 9 3 0 6}$ \\
SAT_2 & 0.5125 & 0.4719 & 0.5189 & 0.7338 & $\mathbf{0 . 9 5 6 2}$ \\
SAT_3 & 0.4834 & 0.507 & 0.539 & 0.7141 & $\mathbf{0 . 9 5 5 2}$ \\
SAT_4 & 0.5553 & 0.579 & 0.5251 & 0.7548 & $\mathbf{0 . 9 4 7 6}$ \\
\hline \hline
\end{tabular}

\section{Path Coefficient Analysis}

Fig. 2 shows the results of path coefficient analysis using PLS. A path coefficient was statistically significant when it $t$-value is greater than 1.96 .

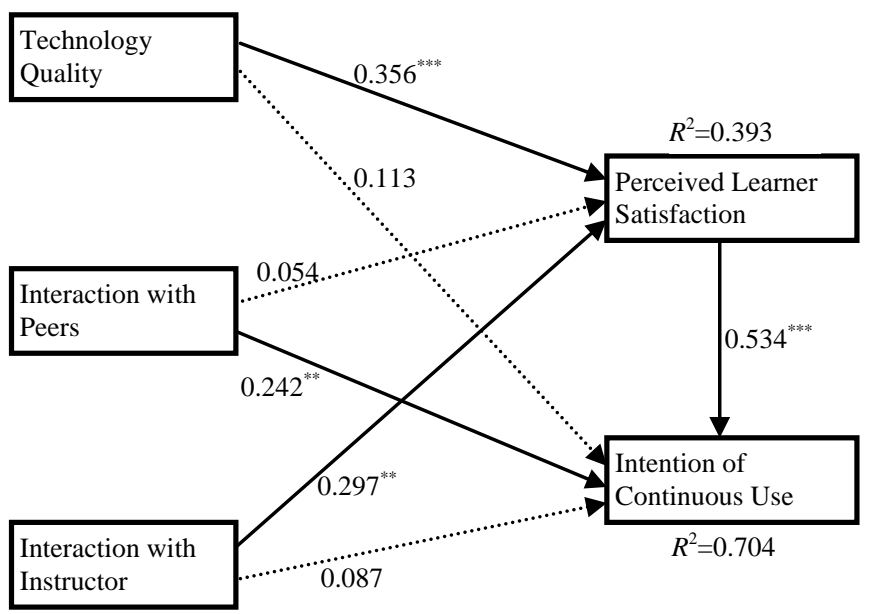

$*$ denotes p-value $<0.1$; ** denotes p-value $<0.05$; *** denotes p-value $<0.01$ Fig. 2. Result of path coefficient analysis.

We found that technology quality would positively influence the perceived learner satisfaction $(\beta=0.356$, $t$-value $=4$.149). Thus, H1 was supported. However, there was no relationship between technology quality and the intention of continuous use $(\beta=0.113, t$-value $=1.580)$. $\mathrm{H} 2$ was not supported. Interaction with peers did not influence perceived learner satisfaction $(\beta=0.054, t$-value $=0.627)$, so we reject $\mathrm{H} 3$. The relationship between the interaction with peers and intention of continuous use was significant $(\beta=0.242$, $t$-value $=2.265)$, thus $\mathrm{H} 4$ was supported. The relationship between interaction with instructor and perceived learner satisfaction $(\beta=0.297, t$-value=2.376) was statistically significant. So H5 was supported. H6 was not supported because the path coefficient between interaction with instructor and the intention of continuous use was not significant $(\beta=0.087, t$-value $=1.147)$. We also found that the perceived learner satisfaction would positively influence the intention of continuous use $(\beta=0.534, t$-value $=6.100)$. Thus, H7 was supported. The results of hypothesis testing are summarized in Table VI.

TABLE VI: RESUlt OF HyPOTHESIS TESTING

\begin{tabular}{lccc}
\hline \hline \multicolumn{1}{c}{ Path } & $\beta$ & $t$-value & Result \\
\hline $\begin{array}{l}\text { Technology Quality } \rightarrow \text { Perceived } \\
\text { Learner Satisfaction }\end{array}$ & 0.356 & 4.149 & H1 Supported \\
\hline $\begin{array}{l}\text { Technology Quality } \rightarrow \text { Intention of } \\
\text { Continuous Use }\end{array}$ & 0.113 & 1.580 & H2 Not Supported \\
\hline $\begin{array}{l}\text { Interaction with Peers } \rightarrow \text { Perceived } \\
\text { Learner Satisfaction }\end{array}$ & 0.054 & 0.627 & H3 Not Supported \\
\hline $\begin{array}{l}\text { Interaction with Peers } \rightarrow \text { Intention of } \\
\text { Continuous Use }\end{array}$ & 0.242 & 2.265 & H4 Supported \\
\hline $\begin{array}{l}\text { Interaction with Instructor } \rightarrow \text { Perceived } \\
\text { Learner Satisfaction }\end{array}$ & 0.297 & 2.376 & H5 Supported \\
\hline $\begin{array}{l}\text { Interaction with Instructor } \rightarrow \text { Intention } \\
\text { of Continuous Use }\end{array}$ & 0.087 & 1.147 & H6 Not Supported \\
\hline $\begin{array}{l}\text { Perceived Learner Satisfaction } \\
\rightarrow \text { Intention of Continuous Use }\end{array}$ & 0.534 & 6.100 & H7 Supported \\
\hline \hline
\end{tabular}

\section{DISCUSSION AND CONCLUSION}

\section{A. Discussion on Results}

\section{1) Technology quality}

The means of the items in the questionnaire regarding technology quality were all above 5.7 (on a 7-point Likert scale), indicating that Facebook Groups offered good user friendly interface, provided easily understandable features, and it was easy to use. We found that Facebook Groups is a well-established social networking website. Learners had no difficulty using it as an electronic platform to support learning. Our experimental results suggested that technology quality would positively influence learners' perceived satisfaction with the course Facebook Groups. Therefore, in order to strengthen learners' satisfaction on the use of an electronic learning tool or system, the designers need to make the interface more intuitive and friendly. Also, the development team needs to make the features easily accessible and understandable.

\section{2) Interaction with peers}

The major difference between the newer digital learning environment (e.g. social networking website) and the traditional digital learning system (e.g. receiving video education) is user involvement. User interaction is normally weak or missing in the traditional digital learning system. Our participants rated that it's easy to communicate, discuss, and interact with peers in the course Facebook Groups. The platform offered them an environment easy to put materials, chat, share, and create activities. Because of the availability to interact with peers, the learners tend to continue to use the Facebook Groups. Our findings suggested that learners not only rely on the easy-to-use system for learning, but also they think the interaction with peers will influence their willingness to continue using the system. Facebook Groups 
for Schools provides the social networking features for learners to interact with peers and the learners are willing to continue using the interactive Groups for learning purpose. However, we did not find any relationship between the peer interaction and learners' perceived satisfaction using Facebook Groups to support learning. It could be due to the fact that users tend to interact with others over the platform because of the nature of the social networking site Facebook. Such interactions won't make them feel that it is effective to use Facebook Groups as a learning support.

\section{3) Interaction with instructor}

The means of the survey items regarding interaction with instructor were all above 5.6, showing that Facebook Groups offered an environment for leaners that they can easily communicate and discuss with their instructor. The traditional e-learning systems allow an instructor to put materials for students to download. These systems provide one-way communications rather than two-way communications which Facebook Groups can offer. On a course Facebook Groups, learners can also ask questions, share information, and post materials. Also, the instructor can provide feedbacks to learners. Our results showed that interaction with instructor would strengthen learners' satisfaction on the use of course Facebook Groups and thus influence learners' intention of continuous use of the Groups.

\section{4) Perceived learner satisfaction}

Based on the survey results, we found that learners were satisfied on using Facebook Groups as a learning support. According to the path coefficient analysis of our research model, we found that the majority of explained variability of the perceived learner satisfaction was contributed by technology quality and interaction with instructor. In addition, the perceived learner satisfaction would hence affect learners' intention of continuous use of the Groups. Therefore, it is suggested to enhance the usability of the e-learning system while providing the capability of interactions between learners and their instructor.

\section{5) Intention of continuous use}

Our participants showed their positive intention of continuous use of the course Facebook Groups. The explained variability of this construct was mainly from interaction with peers and perceived learner satisfaction. Thus, interaction capability of an e-learning system is a crucial factor for learner satisfaction on the system and continuous use of the system.

\section{B. Contributions}

In the past decade, majority of studies focused on varies aspects of traditional digital learning environments. There was relatively limited amount of research examining the newly developed digital learning environments which provided interactivity. Our study not only contributes to research but also to practice. Theoretically, we empirically tested the proposed research model and identified factors influencing learners' intention of continuous use the course Facebook Groups and learners' satisfaction using the Groups as digital online learning support. Technology quality and interaction with instructor were found to affect perceived learner satisfaction. In addition, interaction with instructor and perceived learn satisfaction would influence learners' intention to continuously use the Facebook Groups. Practically, our results suggested that in order to enhance the retention rate of the use of a digital learning environment, the learning system should offer easy to use interface and understandable features, and provide interactivity with other users and instructor. Particularly, we found that Facebook Groups can be used to support a face-to-face course. Practitioners may use Facebook Groups to support learning. Learners could exchange ideas, share information, and interact with others while instructor may act as a facilitator to smooth the interactions and provide necessary guidance.

\section{Limitations and Future Directions}

In this study, we utilized Facebook Groups as an online interactive learning support to a software project management course. Learners' participation to the course Groups was required. The perceived interaction with peers and instructor could be higher than other settings. Also, the participants' self-efficacy on the use of information systems and computer tools could be higher because they majored in Management Information Systems. They may be more adaptable to the learning support using IT. In order to generalize the findings, it is suggested to test the research model again using subjects who have different backgrounds, dependability, and proficiency in information systems and information technology. Also, it is recommended to use other digital learning environments for experiments.

\section{REFERENCES}

[1] N. Snell, Why can't Johnny do client/server? Inside Technology Training, July/August, 1997.

[2] R. P. Bostrom, L. Olfman, and M. K Sein, "The importance of learning style in end-user training," Mis Quarterly, vol. 14, no. 1, 1990.

[3] M. Sein, R. P. Bostrom, and L. Olfman, "Rethinking end-user training strategy: Applying a hierarchical knowledge-level model," Journal of Organizational and End User Computing, vol. 11, no. 1, pp. 32-39, 1999.

[4] S. Gupta, R. P. Bostrom, and M. Huber, "End-user training methods: What we know, need to know," ACM SIGMIS Database, vol. 41, no. 4, pp. 9-39, 2010.

[5] D. H. Choi, J. Kim, and S. H. Kim, "ERP training with a web-based electronic learning system: The flow theory perspective," International Journal of Human-Computer Studies, vol. 65, no. 3, pp. 223-243, 2007.

[6] D. Compeau, L. Olfman, M. Sei, and J. Webster, "End-user training and learning," Communications of the ACM, vol. 38, no. 7, pp. 24-26, 1995.

[7] B. G. Wilson, Constructivist Learning Environments: Case Studies in Instructional Design, Englewood Cliffs, NJ: Educational Technology Publications, 1996.

[8] G. Piccoli, R. Ahmad, and B. Ives, "Web-based virtual learning environments: A research framework and a preliminary assessment of effectiveness in basic IT skills training," MIS Quarterly, vol. 25, no. 4, pp. 401-426, 2001.

[9] W. H. DeLone and E. R. McLean, "Information systems success: the quest for the dependent variable," Information Systems Wesearch, vol. 3, no. 1, pp. 60-95, 1992.

[10] Y. C. Chen, "An empirical examination of factors affecting college students' proactive stickiness with a web-based English learning environment," Computers in Human Behavior, vol. 31, pp. 159-171, 2014.

[11] T. Teo and S. L. Wong, "Modeling key drivers of E-learning satisfaction among student teachers," Journal of Educational Computing Research, vol. 48, no. 1, pp. 71-95, 2013.

[12] V. A. Thurmond, K. Wambach, H. R. Connors, and B. B. Frey, "Evaluation of student satisfaction: Determining the impact of a Web-based environment by controlling for student characteristics," The American Journal of Distance Education, vol. 16, no. 3, pp. 169-190, 2002. 
[13] P. C. Sun, R. J. Tsai, G. Finger, Y. Y. Chen, and D. Yeh, "What drives a successful e-learning? An empirical investigation of the critical factors influencing learner satisfaction," Computers and Education, vol. 50, pp. 1183-1202, 2008

[14] J. C. Nunnally, Psychometric Theory, New York, NY: McGraw-Hill, 1978.

[15] J. F. Hair, R. L. Anderson, and W. C. Tatham, Multivariate Data Analysis with Reading, Upper Saddle River, NJ: Prentice-Hall, 1998.

[16] J. F. Hair, B. Black, B. Babin, R. E. Anderson, and R. L. Tatham, Multivariate Data Analysis, 2006.

[17] C. Fornell and D. F. Larcker, "Evaluating structural equations with unobservable variables and measurement error," Journal of Marketing Research, vol. 18, no. 1, pp. 39-50, 1981.

[18] W. W. Chin, "Issues and opinion on structure equation modeling," MIS Quarterly, vol. 22, no. 1, pp. vii-xvi, 1998.

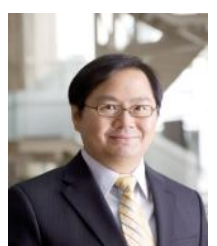

Chen-Huei Chou is an associate professor of management information systems and decision sciences in the School of Business at the College of Charleston, SC, U.S.A. His areas of interests include web design issues in disaster management, ontology development, Internet abuse in the workplace, text mining, and data mining. His research has been published in MIS journals and major conference proceedings, including Journal of Association for Information Systems, Decision Support Systems, IEEE Transactions on Systems, Man, and Cybernetics, Journal of Information Systems and e-Business Management, and Computers in Human Behavior

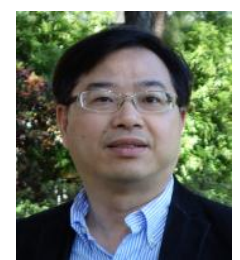

Shih-Ming Pi is a professor of the Department of Information Management at Chung Yuan Christian University in Taiwan. His recent articles can be found in Computers in Human Behavior, Communications of the ACM, European Journal of Information Systems, Journal of the Association for Information Systems, and other Chinese information management journals. 